unions in Britain lobbied the government to create a similar institution here this article would be redundant.

D SNASHALL

Senior Lecturer in Occupational Health,

United Medical and Dental School,

St Thomas's Hospital,

London SEl 7EH

1 Health and Safety Commission. Annual report 1988-89. London: HMSO, 1990

2 Health and Safety Executive. Construction health and safety 1981-82. London: HMSO, 1983.

3 Barry $T$ and Associates. Behavioural analysis of workers and job hazards in the roofing industr. Cincinatti, Ohio: Department of Health Education and Welfare, National Institute of Occupational Safety and Health, 1975 .

4 Office of Population Censuses and Survevs. Occupational mortality. Registrar General's decennial supplement for England and Wales 1970-72. London: HMSO, 1978.

\section{Acid suppression: how much is needed?}

\section{Adjust it to suit the condition}

Many treatments are now available for acid related disorders - and there is sharp competition among their manufacturers. Mucosal protective drugs are much less popular than treatments that neutralise or suppress acid secretion, the most successful of which have been the $\mathrm{H}_{2}$ receptor antagonists. Even more potent acid suppressing drugs have been developed, among which the proton pump inhibitor omeprazole stands out. Unlike the $\mathrm{H}_{2}$ receptor antagonists, which compete for the receptor on the parietal cell, omeprazole inhibits hydrogen-potassium ATPase, the enzyme responsible for secretion of acid. ${ }^{1}$ This is a clinically important difference because once the hydrogen-potassium ATPase is inhibited no acid secretion will follow no matter how vigorously the receptors are stimulated. As omeprazole is long acting achlorhydria can be sustained throughout 24 hours, whereas because the existing $\mathrm{H}_{2}$ receptor antagonists are competitive the inhibitory effect at the receptor can be overridden with a powerful stimulus, such as a meal.

$\mathrm{H}_{2}$ receptor antagonists therefore do not often achieve complete achlorhydria for 24 hours, ${ }^{2}$ even when the dose is increased. Nevertheless, the extent to which acid needs to be neutralised or suppressed varies with the condition being treated: the most potent acid suppressing drugs are not needed in all circumstances.

The aim in clinical practice is to overcome or prevent damage to the mucosa by acid-when that is important. Patients with non-ulcer dyspepsia of the dysmotility type (typically complaining of nausea, distension, and premature satiety) are unlikely to be in danger of such damage. They seem to do well with prokinetic drugs, such as domperidone, metoclopramide, or cisapride. ${ }^{3+}$ Other types of dyspepsia, in which there is some risk of acid damage, may be safely treated without investigation in younger patients (under, say, 45) who have no worrying symptoms. ${ }^{3}$ Depending on the severity and persistence of symptoms, antacids or $\mathrm{H}_{2}$ receptor antagonists may be given as single courses of treatment.

When peptic ulceration or mucosal damage from acid is diagnosed, however, or when there is a risk of it occurring or recurring, a reliable means either of reducing acid secretion or of protecting the mucosa needs to be offered. Peptic ulcers heal well with acid suppression, and there is an excellent correlation between the degree of acid suppression (especially overnight) and the percentage of duodenal ulcers that heal. Modest acid reduction heals about $60 \%$ whereas profound reduction heals virtually $100 \% .^{5}$ Reducing gastric acid con- centrations at night, when the acid is not needed, seems attractive, and a single nighttime dose gives virtually identical healing rates to a divided dose and might aid patient compliance. ${ }^{56}$ Giving the $\mathrm{H}_{2}$ receptor antagonists with the evening meal may prolong its acid suppressing effect but is

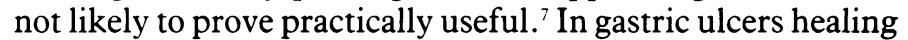
shows a better correlation for reduction of 24 hour acidity than with overnight acidity. ${ }^{8}$ Mucosal factors pay a larger part in gastric ulcer, which may need 12 weeks' treatment with an $\mathrm{H}_{2}$ receptor antagonist and endoscopic monitoring.

Clinically there is little to choose between the four $\mathrm{H}_{2}$ receptor antagonists currently available, all of which are remarkably effective and safe. ${ }^{90}$ Cimetidine is less potent than ranitidine, nizatidine, or famotidine and has clinically important interactions with some drugs - notably with anticonvulsants, theophyllines, and warfarin-the hepatic metabolism of which it inhibits by binding to cytochrome $P-450 .{ }^{11}$ A meta-analysis comparing cimetidine with ranitidine showed a small advantage for ranitidine of $7 \%$ in healing rates over a one month treatment period, ${ }^{12}$ but such a difference is undetectable to the individual prescriber and must be offset against cimetidine being much cheaper. The newer compounds nizatidine and famotidine are similar in efficacy to ranitidine and have no appreciable advantage, both being more expensive than cimetidine.

The $\mathrm{H}_{2}$ receptor antagonists heal about $75 \%$ of duodenal ulcers with four weeks' treatment, rising to over $90 \%$ at eight weeks. A healing course should probably be six weeks for non-smokers and eight weeks for smokers. ${ }^{13}$ Changing the antagonist is unlikely to heal a resistant ulcer, although increasing the dose may help..$^{14}$

About $5-20 \%$ of duodenal ulcers do not heal with an $\mathrm{H}_{2}$ receptor antagonist and need more profound acid suppression, such as can be achieved with omeprazole. Omeprazole heals almost all duodenal ulcers in two to four weeks, swiftly relieves symptoms, and is now the treatment of choice for resistant duodenal ulcers-until eradication of Helicobacter pylori becomes more simple and effective.

Concerns have been raised, however, over the long term safety of such profound and sustained acid inhibition. Firstly, about a third of female rats taking very high dose omeprazole over most of their lifespan developed carcinoid-like tumours in the stomach. These tumours may be related to high concentrations of circulating gastrin consequent on achlorhydria, as antrectomy prevented an increase in the density of enterochromaffin-like cells, ${ }^{15}$ which is much greater in the rat stomach than in humans. Carcinoid-like tumours are uncommon in pernicious anaemia, where gastrin concentrations are much higher than in patients treated with omeprazole. ${ }^{16}$ This then is unlikely to be an important cause for concern. Secondly, bacterial overgrowth in the stomach due to the achlorhydria is feared to lead to production of carcinogens from food contaminants. This hypothesis was originally raised with cimetidine, with which it has now been largely discounted, ${ }^{17}$ but it may be different with profound acid inhibition over a long period. Thirdly, a recent suggestion is that omeprazole may itself be genotoxic - that is, be capable of leading to the development of cancer. Glaxo laboratory scientists have published their own technique for screening for potential carcinogenicity of acid inhibiting drugs. ${ }^{18}$ They claim that omeprazole had a genotoxic effect in their test whereas ranitidine did not. Their technique has not been validated by any other group and has been heavily criticised $^{19.21}$-appropriately, in my opinion. Until more information is available this claim should be discounted. None the less, omeprazole is a new compound, and until more is known of its longer term safety the aim should be to use it in resistant ulcers and only for short term treatment. Longer 
term treatment of the Zollinger-Ellison syndrome with omeprazole is, however, effective and safe. ${ }^{22}$

The whole range of treatments, from antacids to total inhibition, are needed in gastro-oesophageal reflux disease. Here the acid reflux ranges from a slight increase to severe and prolonged exposure of the oesophageal mucosa to acid ${ }^{23}-$ often resistant to conventional treatment. Multiple trials have shown that for the milder types of oesophagitis (grades 1 and 2) the $\mathrm{H}_{2}$ receptor antagonists combined with antacids are effective in most cases. ${ }^{2+}$ Treatment, however, often relieves symptoms better than it heals, and commonly has to be continued for two months or more and sometimes indefinitely. Increasing the dose of the $\mathrm{H}_{2}$ receptor antagonist may improve the healing rate a little.

The more severe the oesophagitis (grade 3, circumferential inflammation; grade 4, deep ulcerations or a stricture) the greater the degree of acid suppression usually needed to achieve healing. The patients do particularly well with omeprazole. ${ }^{25}$ Here the difference in efficacy between the $\mathrm{H}_{2}$ receptor antagonists and omeprazole is sharp, with two month healing rates across the range of oesophagitis for omeprazole reaching more than $85 \%$ compared with about $40-60 \%$ with $\mathrm{H}_{2}$ receptor antagonists. ${ }^{2426}$ Patients with severe symptoms or dysphagia should be assessed endoscopically to confirm the diagnosis. High dose $\mathrm{H}_{2}$ receptor antagonists and alginate antacids may be tried, but if these are not fully effective omeprazole should then be used. Symptoms often improve considerably with omeprazole, and the patient may well press the doctor hard for renewal of the prescription, but it is licensed only for short term use. So at present, after a two month course of omeprazole at a dose of $20 \mathrm{mg}$ (but not all patients respond to $20 \mathrm{mg}$, and $40 \mathrm{mg}$ may be needed) full dose maintenance with an $\mathrm{H}_{2}$ receptor antagonist would seem practical, with the course of omeprazole being repeated later if needed. If this approach produces no relief it would be reasonable to treat continuously, especially in the elderlybut only after discussing the implications with the patient. Although omeprazole seems to be safe, however, uncertainty about its long term effects raises a question over this option for younger patients until we have more experience of proton pump inhibitors. Nowadays acid suppression really can be adjusted to suit the patient, but care should be exercised, especially with newer, very powerful compounds.

D G COLIN-JONES

Consultant Physician and Gastroenterologist,

Queen Alexandra Hospital,

Portsmouth PO6 3LY

1 Soll AH. Review: antisecretory drugs: cellular mechanisms of action. Alimentary Pharmacology and Therapeutics 1987;1:77-9.

2 Merki HS, Halter F, Wilder-Smith C, et al. Effect of food on $\mathrm{H}_{2}$-receptor blockade in normal subjects and duodenal ulcer patients. Gut 1990;31:148-50.

3 Colin-Jones DG. Management of dyspepsia: a report of a working party. Lancet 1988;i:576-9.

Dobrilla G, Comberlato M, Steele A, Vallaperta P. Drug treatment of functional dyspepsia. $\mathcal{F}$ Clin Gastroenterol 1989;11:169-77.

Chiverton SG, Hunt RH. Medical regimens in short- and long-term ulcer management. Baillieres Clin Gastroenterol 1988;2:655-76.

6 Ireland A, Colin-Jones DG, Gear P, et al. Ranitidine $150 \mathrm{mg}$ twice daily versus $300 \mathrm{mg}$ nightly in treatment of duodenal ulcers. Lancet 1984;ii:274-6.

7 Merki H, Witzel L, Harre K, Scheurle E, Neuman J. Single dose treatment with $\mathrm{H}_{2}$-receptor antagonists: is bedtime administration too late? Gut 1987;28:451-4.

8 Howden CWW, Hunt RH. The relationship between suppression of acidity and gastric ulcer healing rates. Alimentary Pharmacology and Therapeutics 1990;4:25-33.

9 Lee FJ, Booth SN, Cochran KM, et al. Single night-time doses of $40 \mathrm{mg}$ famotidine or $800 \mathrm{mg}$ cimetidine in the treatment of duodenal ulcer. Alimentary Pharmacology and Therapeutics 1989;3:505-12.

10 Porro GB, Keohane PP, eds. Nizatidine in peptic ulcer disease: proceedings of the first international symposium on nizatidine. Scand $\mathcal{F}$ Gastroenterol 1987;22(suppl 136): 1-88.

11 McGuigan JE. Side effects of histamine-2-receptor antagonists. Clinics in Gastroenterology

12 McIsaac RL, McCanless I, Summers K, Wood JR. Ranitidine and cimetidine in the healing of duodenal ulcer: meta-analysis of comparative clinical trials. Alimentary Pharmacology and Therapeutics 1987;1:369-81

13 Chiverton SG, Hunt RH. Smoking and duodenal ulcer disease. $f$ Clin Gastroenterol 1989;11(suppl 1):29-33

14 Page MC, Lacey LA, MillS JG, Wood JR. Can higher doses of an $\mathrm{H}_{2}$-receptor antagonist accelerate duodenal ulcer healing? Alimentary Pharmacology and Therapeutics 1989;3:425-33.

15 Larsson $\mathrm{H}$, Carlsson E, Mattsson H, et al. Plasma gastrin and gastrin enterochromaffin-like cell activation and proliferation. Gastroenterology 1986;90:391-9.
16 Lanzon-Miller S, Pounder RE, Hamilton MR, et al. Twenty-four-hour intragastric acidity and plasma gastrin concentration in healthy subjects and patients with duodenal or gastric ulcer, or mentary Pharmacology and Therapeutics 1987;1:225-37.

17 Colin-Jones DG, Lawson DH, Langman MJS, et al. Post-cimetidine surveillance for up to ten years: incidence of carcinoma of the stomach and oesophagus. Qf Med 1990 (in press).

18 Burlinson B, Morris SH, Gatehouse DG, Tweats DJ. Genotoxicity studies of gastric acid inhibiting drugs. Lancet 1990;335:419.

19 Anonymous. Omeprazole and genotoxicity [Editorial]. Lancet 1990;335:386.

20 Wright NA, Goodlad RA. Omeprazole and genotoxicity. Lancet 1990;335:909-10.

21 Helander HF, Larsson H, Carlsson E. Omeprazole and genotoxicity. Lancet 1990;335:910.

22 Lloyd-Davies KA, Rutgersson K, Sölvell L. Omeprazole in the treatment of Zollinger-Ellison syndrome: a 4-year international study. Alimentary Pharmacology and Therapeutics 1988:2:13-32. Joelsson B, Johnsson F. Heartburn - the acid test. Gut 1989;30:1523-5.

24 Colin-Jones DG. Histamine-2-receptor antagonists in gastro-oesophageal reflux. Gut 1989;30: $1305-8$.

25 Havelund T, Laursen LS, Skoubo-Kristensen E, et al. Omeprazole and ranitidine in treatment of reflux oesophagitis: double-blind comparative trial. $\mathrm{Br} M e d$ f 1988;296:89-92.

26 Klinkenberg-Knol EC, Jansen JMBJ, Festen HPM, Meuwissen SGM, Lamers CBHW. Doubleblind mulvicentre comparison of omeprazole and ranitidine in the treatment of reflux oesophagitis. Lancet 1987;i:349-51.

\section{Diabetic autonomic neuropathy}

\section{A common complication which rarely causes symptoms}

Autonomic neuropathy has been recognised as a common complication of diabetes mellitus for many years. ${ }^{1}$ Often asymptomatic and diagnosed only on routine screening, it is, indeed, usually defined on the basis of abnormal results of tests of the autonomic nervous system. ${ }^{1}$ Using data from cross sectional studies, Ewing and Clarke have suggested that the sequence of autonomic damage begins with loss of sweating in the feet, impotence, and bladder dysfunction, and progresses through abnormalities in the cardiovascular reflexes to a final stage of symptomatic postural hypotension, sweat disturbances of the upper body, gastroparesis, diarrhoea, and bladder atony. ${ }^{1}$ This sequence cannot be inevitable, however, as symptomatic patients are so rare. ${ }^{2} \mathrm{~A}$ recent community survey in Britain found a single abnormal cardiovascular autonomic response in $16 \%$ of patients with diabetes (both insulin dependent and non-insulin dependent $)^{2}$; this prevalence is similar to reported values from randomly selected, hospital based populations. ${ }^{3}$ Although it can affect most body systems, symptomatic autonomic neuropathy is much less well defined ${ }^{1}$ and may be more common in insulin dependent patients. ${ }^{2}$ The annual incidence is unknown, although abnormal cardiovascular reflexes can be found after only two years of insulin dependent diabetes. ${ }^{4}$

Symptomatic patients have a poor prognosis with up to half of them dying within five years in the most widely quoted series. ${ }^{5} \mathrm{~A}$ recent editorial, however, reported lower mortality figures of $27 \%$ for symptomatic patients and $10 \%$ for asymptomatic patients after 10 years of follow up. ${ }^{6}$ Many of the patients concerned, however, had coexistent nephropathy, and the impact of the autonomic neuropathy alone is not clear. Sudden cardiopulmonary arrest has been described in symptomatic patients, often in association with general anaesthesia, ${ }^{7}$ and this may be related to defects such as prolongation of the QT interval ${ }^{89}$ or to silent myocardial infarction..$^{10} \mathrm{~A}$ prospective study of a group of 17 diabetic patients undergoing eye surgery showed that $35 \%$ required treatment with a vasopressor during surgery compared with only $5 \%$ of non-diabetic controls, and those with worse autonomic dysfunction tended to need intervention more frequently. ${ }^{11}$

How, then, is autonomic neuropathy diagnosed? The many tests of autonomic function have been extensively reviewed. ${ }^{12} \mathrm{~A}$ consensus statement from the American Diabetes Association and the American Academy of Neurology has recommended three tests for routine assessment of autonomic function: firstly, heart rate responses to Valsalva's 